\title{
Olanzapine: is it enough for CINV prevention?
}

\author{
Piyawan Tienchaiananda ${ }^{1}$, Wipada Nipondhkit ${ }^{2}$, Naiyarat Prasongsook ${ }^{3}$ \\ ${ }^{1}$ Oncology Unit, Department of Medicine, Rajavithi Hospital, Bangkok, Thailand; ${ }^{2}$ Chemotherapy Department, Udonthani Cancer Hospital, \\ Udonthani, Thailand; ${ }^{3}$ Medical Oncology Unit, Department of Medicine, Phramongkutklao Hospital, Bangkok, Thailand \\ Correspondence to: Piyawan Tienchaiananda. Oncology Unit, Department of Medicine, Rajavithi Hospital, Rachwithi Road, Ratchathewi District, \\ Bangkok 10400, Thailand. Email: pt_kuk@hotmail.com. \\ Provenance and Peer Review: This article was commissioned and reviewed by the Academic Editor Dr. Jia Zhu (Shenyang Pharmaceutical University, \\ Shenyang, China). \\ Response to: Navari RM, Loprinzi CL. Olanzapine is an effective antiemetic agent. Ann Palliat Med 2020. doi: 10.21037/apm.2020.04.32.
}

Submitted Apr 23, 2020. Accepted for publication May 09, 2020.

doi: 10.21037/apm-20-1018

View this article at: http://dx.doi.org/10.21037/apm-20-1018

The area postrema and nucleus tractus solitarius are an important source of afferent input to the central pattern generator (CPG) and also are a main site of neurokinin-1 (NK1), serotonin [5-hydroxytryptamine (5-HT)], muscarinic (M1), dopamine (D2), and histamine (H1) receptors. Olanzapine inhibits several neurotransmitter receptors, which most of those neurotransmitter receptors involve with vomiting reflex. Although, olanzapine mainly inhibits 5-HT2 receptor. However, the pathophysiology of chemotherapy-induced nausea and vomiting (CINV) demonstrated that there are not only 5-HT3 and NK-1 receptors in vagal afferent nerves directly involved with the CPG, but also central 5-HT2, dopamine, serotonin, histamine, GABA and cannabinoid receptors are partly stimuli an emetogenic reflex causing nausea/vomiting either acute or delay type (1).

Multiple international guidelines have recommended olanzapine in combination with dexamethasone, 5-HT antagonists with or without NK1 receptors antagonists for prevention of CINV from high to moderate emetogenic chemotherapy regimen $(2,3)$. The interesting question is whether the role of NK1 receptor antagonists in four-drug regimen regarding to its efficacy and cost effectiveness.

A randomized phase III trial evaluated the effectiveness of olanzapine $10 \mathrm{mg}$ versus aprepitant while all patients received palonosetron and dexamethasone. The complete response rate in all periods and the proportion of patients without nausea in the acute period was not different between both treatment arms (4). NCCN panel recommends an olanzapine-containing three- drug regimen with palanosetron and dexamethasone, since; there was no large clinical trial available for the other 5-HT3 antagonists (2). However, several phase II trials also supported the superiority efficacy in terms of nausea control by olanzapine $10 \mathrm{mg}$ in combination with ondansetron plus dexamethasone when compared to the standard dose of aprepitant in combination $(5,6)$. Our study also demonstrated the efficacy of olanzapine $10 \mathrm{mg}$ in the three-drug regimen with ondansetron and dexamethasone in terms of the nausea control and the complete response rate in acute phase (7). Additionally, a systematic review of NK-1 receptor antagonist, 5-HT3 antagonist and dexamethasone revealed $72 \%$ complete response rate in the acute phase which was similar to $75 \%$ complete response rate in the acute phase from olanzapine, ondansetron and dexamethasone in our study $(7,8)$.

There are not only disparities in access to active cancer treatment but also to supportive care such as prevention of CINV are well established between low- and highincome countries. There were racial disparities in use of NK1 receptor antagonists for CINV prevention among breast cancer patients in the United States (9). The authors concluded that the affordability to the NK1 receptor antagonists may partly be explained these disparities. A multinational study in Southeast Asia including Thailand demonstrated the cost effectiveness of olanzapine in addition to dexamethasone and first generation 5-HT3 antagonist. In Singapore, switching aprepitant to olanzapine in three-drug regimen increased 0.0005 QALY with cost saving of USD 60.91 (10). 
Moreover, drug to drug interaction should be considered when prescribing of NK-1 receptor antagonists with other drugs, which they are metabolized by cytochrome $\mathrm{P} 450$. Regarding to NK-1 receptor antagonists are moderate inhibitors of the CYP3A4 metabolic pathway, dose reduction should be required for co-administered drugs that are metabolized through CYP3A4. For example, aprepitant will increase the effect or level of dexamethasone by affecting hepatic/intestinal enzyme CYP3A4 metabolism. Dexamethasone where is CYP3A4 inducer has been routinely reduced dose when administered with these NK1 receptor antagonists. On the other hand, olanzapine is mainly metabolized by CYP1A2, with CYP2D6, and UGT as minor pathways. Thus, dose reduction of concurrently administered drugs may be not needed. Our study used higher dose of glucocorticoid, which was $20 \mathrm{mg}$ of dexamethasone with olanzapine. It may synergistically enhance inhibitory effect of corticosteroid on central pathways including reducing the permeability of the blood brain barrier to chemicals, depleting the inhibitory GABA in medullary antiemetic neurons, and reducing leuenkephalin release in the brainstem.

To conclude, olanzapine $10 \mathrm{mg}$ in the three-drug regimen with ondansetron or palanostron plus dexamethasone is one of the treatment options for CINV prevention from high to moderate emetogenic chemotherapy regimens regarding to efficacy, affordability and lower drug to drug interaction. However, large phase III randomized studies to compare efficacy and safety between olanzapine versus NK-1 receptor antagonist in combination regimen are required.

\section{Acknowledgments}

Funding: None.

\section{Footnote}

Conflicts of Interest: All authors have completed the ICMJE uniform disclosure form (available at http://dx.doi. org/10.21037/apm-20-1018). The authors have no conflicts of interest to declare.

Ethical Statement: The authors are accountable for all aspects of the work in ensuring that questions related to the accuracy or integrity of any part of the work are appropriately investigated and resolved.

Open Access Statement: This is an Open Access article distributed in accordance with the Creative Commons Attribution-NonCommercial-NoDerivs 4.0 International License (CC BY-NC-ND 4.0), which permits the noncommercial replication and distribution of the article with the strict proviso that no changes or edits are made and the original work is properly cited (including links to both the formal publication through the relevant DOI and the license). See: https://creativecommons.org/licenses/by-nc-nd/4.0/.

\section{References}

1. Frame DG. Best practice management of CINV in oncology patients: I. Physiology and treatment of CINV. Multiple neurotransmitters and receptors and the need for combination therapeutic approaches. J Support Oncol 2010;8:5-9.

2. NCCN. Antiemesis. In: NCCN Clinical Practice Guideline in Oncology. version 1. 2020.

3. Walsh D, Davis M, Ripamonti C, et al. 2016 Updated MASCC/ESMO consensus recommendations:

Management of nausea and vomiting in advanced cancer. Support Care Cancer 2017;25:333-40.

4. Navari RM, Gray SE, Kerr AC. Olanzapine versus aprepitant for the prevention of chemotherapy-induced nausea and vomiting: a randomized phase III trial. J Support Oncol 2011;9:188-95.

5. Rumyantsev A, Glazkova E, Nasyrova R, et al. Olanzapine (OLN) versus aprepitant (APR) in patients receiving highemetogenic chemotherapy: Final results of randomized phase II trial. J Clin Oncol 2019;37:11504.

6. Ithimakin S, Theeratrakul P, Laocharoenkiat A, et al. Randomized, double-blind, placebo-controlled study of aprepitant versus two dosages of olanzapine with ondansetron plus dexamethasone for prevention of chemotherapy-induced nausea and vomiting in patients receiving high-emetogenic chemotherapy. Support Care Cancer 2020. [Epub ahead of print].

7. Tienchaiananda P, Nipondhkit W, Maneenil K, et al. A randomized, double-blind, placebo-controlled study evaluating the efficacy of combination olanzapine, ondansetron and dexamethasone for prevention of chemotherapy-induced nausea and vomiting in patients receiving doxorubicin plus cyclophosphamide. Ann Palliat Med 2019;8:372-80.

8. dos Santos LV, Souza FH, Brunetto AT, et al. Neurokinin-1 receptor antagonists for chemotherapyinduced nausea and vomiting: a systematic review. J Natl Cancer Inst 2012;104:1280-92. 
9. Check DK, Reeder-Hayes KE, Basch EM, et al. Investigating racial disparities in use of NK1 receptor antagonists to prevent chemotherapy-induced nausea and vomiting among women with breast cancer. Breast Cancer Res Treat 2016;156:351-9.

Cite this article as: Tienchaiananda P, Nipondhkit W, Prasongsook N. Olanzapine: is it enough for CINV prevention? Ann Palliat Med 2020;9(4):2427-2429. doi: 10.21037/apm-20-1018
10. Chanthawong S, Lim YH, Subongkot S, et al. Costeffectiveness analysis of olanzapine-containing antiemetic therapy for managing highly emetogenic chemotherapy in Southeast Asia: a multinational study. Support Care Cancer 2019;27:1109-19. 